\title{
Local Self-Governments as New Actors in the International Stage. The Scope of the Issue
}

\begin{abstract}
The aim of the article is to present, in a short and a synthetic form, self-governments as new actors on the international arena. Discussed are the genesis and the development of this new international activities being undertaken by local residential areas such as the "twinning movement" and the programme for establishing "sister cities". Briefly described are the key international organizations focused on the local self-governance. Discussed is also, in a relative detail, is the cooperation of the Polish self-governance entities with local self-governance partners within the international sphere. The author concludes by attempting to define the scope and importance of the international cooperation of local self-governance entities in general and its impact on the individual participating partners.
\end{abstract}

Keywords: local self-governance, international cooperation, international stage

\section{Introduction}

The local self-governance constitutes a substantial and constantly raising in a significant element of the international scene. The growing importance of the local self-governance is evoked directly in part by the changes occurring in the global and the local socio-economic environment. It is also largely stimulated and impacted by a direct interaction with the members of various local self-governance entities from numerous countries within the international arena, who participate and interact with each other during general in nature or dedicated to issues, meetings, conferences and other venues. This direct interaction that takes place among various local self-governances greatly enhances and enriches relationships among representatives of different nationalities, different local community structures and ethnic, cultural and religious backgrounds and identities. It promotes and further develops the self-governance based civic spirit and helps to build upon and expand the interpersonal and interorganizational relationships. It precisely the types of interactions between the members of various countries at the level of local communities and not only by the national 
governments that result in bringing communities and nations closer to one another by deformalizing and personalizing interactions. It is through these kinds of interactions that ideas, knowledge and experiences developed and tried by the local communities are being shared, evaluated, exchanged, adapted and promulgated into different communities. People representing these communities become acquainted, develop professional and personal relationships and bond through participation with other members of self-governing communities in different states. Such collaboration and active working partnerships appear to be not only conducive, but critical to breaking down walls of prejudices that are rooted in false stereotypes and ignorance. Said collaboration is indispensable in today's global world if we are to develop the new face of international relations that are built on cooperation and exchange of ideas and not on wars and prejudices and can be shared between communities living within different geographically and politicly defined territories ${ }^{1}$.

The limited size of the publication herein had allowed the writer only to talk about the general theoretical account of this complex subject. However, the aim of the discourse herein is to present, within the limitations of the allotted space, the changes regarding the geographical and spatial scope of impact by the activity of the self-governed territorially defined local communities on their own functioning and on the functioning of the international environment as a whole.

Helpful in reaching the stated aim will be the verification of the hypothesis of the discourse that it were the development of the self-governments, particularly in the second half of the $20^{\text {th }}$ century - which constituted a significant element of democratization of states and the post WWII globalization that caused a situation in which the multi-level cooperation and various working networks existing between the local self-governments had become an significant and interwoven element of the international socio-political environment. Although, somewhat elusive and not very spectacular on the surface, in reality becoming more and more significant as an element of bringing about increased cooperation, lowering and/or breaking down barriers, defusing conflicts and building a platform for an open, creative and partner cooperation among various states.

\section{The Beginnings}

The oldest forms of international activities in terms cooperation among territorially defined local communities can be found in antiquity, such as the Greek police, which were a part of the national organization, but with a local radius. There was also the dominated by Sparta, and military in nature, Peloponnesian League that existed from the $6^{\text {th }}$ to the $4^{\text {th }}$ centuries BC. There was also the Athenian League (or the Delian League) which was an alliance of

1 Regarding the character and the specificity of the international contacts of local self-governments see Honka, 2002; Jóskowiak, 2003; Modzelewski, Żukowski, 2007; Piasecki 2002; Ruszkowski, 2003; Swianiewicz, 2005. 
Greek city states formed in $5^{\text {th }} \mathrm{BC}$ and led by Athens to protect and liberate eastern Greekcity states from Persians. Following the period of Persian-Greek wars the member states enter a state of war between themselves which turned into the 30 years long Peloponnesian War which ended in $404 \mathrm{BC}$ with the victorious takeover of Athens. Both discussed alliances did not have a character of local self-governing bodies, they were rather military alliances of local but still city-states and not local communities per se and with the military agreements starting soft and later growing stronger to almost borderline with confederation (Jaczynowska, Mączkowa, Tyloch, 1974, pp. 197, 211-213.)

Another form of international collaboration of local communities which were organized in a and true to the Medieval period manner, yet already in a form of a self-governments of cities were the Medieval trading organizations also called Hansa(s) (German de Hanse). The first of these, created in the $12^{\text {th }}$ century, was the association of the Netherland cities. During the following century a next Hansa comprised of 15 Flemish cities led by Burges. It was confusingly referred to as the London Hansa even though the city of London was not among the Hansa members. The name resulted from the fact that the merchants associated mainly for trading English wool. Another Hansa was comprised by 17 cities of Northern France and Southern Netherlands and was led by the city of Arras. The largest and the most influential of all the leagues was the Hanseatic League. The established in the 13-century association comprised of the Northern German and other Baltic cities reach the peak of its strength in the 14 and 15 centuries (Samsonowicz, 1958).

At the core of the Hanseatic League was the cooperation by "Baltic Veneti" cities of Lubeck, Wismar and Rostock. Later, joined by Hamburg, Burges and London. At its peak the league was comprised of more than 160 cities, including such Polish cities as Cracow, Torun, Elbląg and Gdańsk. What started as merchant association became a great economic and political power. The German (Hanseatic) League conducted wars and imposed its will even over the royalties (the 14-century war with Denmark). At the beginning of the 15 century the domination of the league begun to weaken. It could not withstand the competition with such economic and political powers like England and Holland. To the weakening position of the Hanseatic league contributed also the internal competition for power and position among the member cities of the League, which were also intertwined into the political and economic situations of the countries on which territories they we located. The League fall in the $16^{\text {th }}$ century. The last summit of the Hanseatic League took place in 1669. However, the 400 hundred plus years of the existence of the so-called German Hansa, which was German mostly in the name only, had demonstrated the potential that can be brought about by solidary cooperation by cities and local-governances. Even today many cities- former members of the Hansa - are very proud of their Hanseatic heritage and the local government activists and leaders are using the Hanseatic League example when talking about the successes brought about by the cooperation of local communities².

2 The Association of New Hansa has been established and continues in operation since 1980, largely 


\section{The Start and Growth of the "Twinning" and the "Sister Cities" Movements}

The contemporary local-governments are characteristic for the modern law obeying democratic nations and civil and mass societies that were developed in the 20-century looking at it not chronologically but historically. From the said perspective, the $20^{\text {th }}$ century began in 1918 with the end of the First World War (WWI). It was WWI that ended the period called the "Modern Era" and started the "Contemporary Era". It was the period after WWI that brought about the first cooperation agreements entered by local communities and their self-governing bodies.

After the end of the horrendous was that brought about the death of a dozen or so million people the existing then democratic societies began to search for ways to bring nations and societies closer the prevent another war from happening or to at least lower the possibility of another such disaster taking place. The military alliances entered during WWI by democratic states were to be kept and expanded upon to jointly keep Europe at peace. The war allies -the Brits and the French - were to build and expand their friendship and cooperation to stand guard in the preservation of Peace not only through cooperation at the national level of state governments and administrations, but also through cooperation by local communities and their self-governances and individual citizens. It was in such a social climate in which many forms of cooperation and contacts were developed between local counties, villages and small cities of Northern France and Southern England. (Brzozowska, 1998). However, this brought about by military alliances cooperation by local communities did not have a mass character as it involved only several dozen local communities.

The mass scale cooperation among local communities and their self-governing bodies began after the even more tragic Second World War (WWII), brutality of which and damages caused by had exceeded all imaginable barriers. The fatalities exceed 80 million both in combat and as victims of mass extermination. The cooperation of local communities and their self-governances was to be one of the methods of rebuilding trust and cooperation as partners between the yesterday enemies. The first bi-lateral cooperation agreement was signed in 1950 by the representatives of two nations conflicted with one another for centuries and whose conflicts imposed many hardships on other European nations and impacted the history of Europe in general. The signatories were the German city Ludwigsburg and the French city of Montbelliard (https://www.ludwigsubrg...,25.05.2018). This was an icebreaker. The representatives of local communities and the local self-governance administrations on both sides began to engage in building of the new friendly and common Europe. The fact that the first agreement was entered by the German and the French was not only a groundbreaking event it was also powerfully symbolic giving a clear message to the world that representatives of historically conflicted nations had turned a new leaf and that new, better

referring to the traditions of the German Hansa (Modzelewski, Żukowski, 2007, pp. 17-18). 
winds began to blow over the Old Continent bringing the time of reconciliation, cooperation and peace. It this new and positive climate the Council of European Municipalities (CEM) was established in 1951. This was the first in Europe multinational organization affiliating local municipalities and their self-governances. In 1984, CEM was expanded to include the regional self-governances and changed the name to the Council of European Municipalities and Regions-CEMR (Kaczmarek 2005, p. 307).

The originated by Ludwigsburg and Montbellier movement of twin city and later twin region cooperation quickly took on and began to grow and expand. With time it spread out of Germany and France over to the Benelux Union, Italy, Switzerland and Great Britain with municipalities and the self-governments of Great Britain entering, similarly to France, into agreements with their German counterparts. Thus, a two form of collaboration on the municipality level were established. One being the direct cooperation of municipalities with their counterpart abroad and two the establishment of international organizations that affiliate the local self-governances. Both became the tools and the important components of the process of integrating of Western Europe. Worthy of notice is fact that the 1950s were the years when three very important organizations were created: The European Coal and Still Community (ECSC), established 1952, the European Atomic Energy Community (EAEC), established in 1958, and the European Economic Community (EWG), established in 1957 (Faliński, 2011).

In parallel, on the other side of the Atlantic Ocean in the United States of Northern America (USA), an analogical movement of local municipalities and their self-governances, rooted in the democratic values with an aim toward international cooperation, was being born. Its goal, similarly to Europe, was to build civil societies and develop friendly relationships among different and often previously hostile toward one another communities and individuals of various nations affected and divided by WWII. The new ties and relationships were to be first established through reaching out going through a process of introduction to be later elevated to friendly cooperation of municipalities and their self-governances and not only within the limits of one continent as it was happening in Europe but worldwide. Such an initiative was announced and promoted in 1956 by then US President Dwight Eisenhower, who named the initiative a "Civil Democracy". The initiative was embraced by numerous cites throughout the US and was named "Sister cities". First it was introduced in Japan, then China, Korea, Vietnam and later other countries of Asia, Near East and Africa, and finally - but it was in the 90ties, after the fall of the Soviet Union) Russia and other countries that emerged after the end of the Soviet empire (Paczyńska, Stachowiak, Porawski, Leki, 2009, p. 4).

\section{International Organizations of Municipal Self-Governances}

The established in 1951 CEM started the process of growth of various international organizations affiliating municipalities and their governments. In 1984 it enlarged its scope and outreach by including the self-governances at a regional level and took on an adequate name 
of the Council of European Municipalities and Regions. Today CEMR is the largest, most specialized and self-contained international organizational structure. Its membership is comprised of national organizations that affiliate individual municipalities in their respective countries, but it is not rare that there are more organizational members than one from a country. Now the direct membership is comprised of 60 organizations from 42 countries but represented are more than $130 \mathrm{~K}$ local self-governances of several types and size (http:// www.ccre.org/31.05.2018).

CEMR itself is a section of the established in Paris in 2004 worldwide agreement of the self-governances - the United Cities and Local Governments (ULCLG). Among its members, aside from CEMR, are UCLG Africa; USLG Asia-Pacific; UCLG; UCLG-Eurasia; UCLG Middle East and West Asia; UCLG Latin America; Coordination of Local Authorities for Unity and Diversity-CORDIAL; UCLG North America; Metropolitan Section, Metropolis Forum of Regions - UCLG MSMFR. In total UCLG affiliates more than 240 territorial self-governances that are members of more than 175 national level association coming from more than 140 countries. Analysis of data shows that the greatest number of direct and indirect members come from Europe although Europeans do not dominate on the management board level of UCLG. This is also reflected by the locations of the UCLG summits. While the first (2004) was held in Paris the subsequent were held in Jeju (2007); Mexico City (2010); Rabat (2013); and Bogota (2016) (https://www.uclg.org/,31.05.2018).

An interesting type and of a growing importance are international organizations affiliating local self-governances are specialized networks that affiliate specific and singular in relation to others self-governances. The singularity can be expressed by size, geographical typology or location or a standing within the general framework of the administrative powers of the country or a region. The Assembly of European Regions (AER) is a good example of a said structure. It was established in 1987. Its membership is comprised of the representation of more than 270 regions and the representation of 33 national level organizations all coming from 35 countries. It provides a forum for cooperation by diverse in character and European regions which positions are different depending on the political and economic regime of the country of origin i.e. unitary state, federation, regional, and the location i.e. member of the EU or not (htpps://aer...,31.05.2018). Another such network is the established in 1986, European Association of Metropolitan Cities (Eurocities). Members to this agreement are cities with population exceeding 250k inhabitants. The Membership of this body is comprised of more than 185 big cities with combined inhabitance of more than 130 million that are in 39 countries (http://www.eurocities...,31.05.2018). Yet another, also metropolitan network of local self-governances, is the Union of Capitals of European Union (ECEU). The traditions of ECEU go back to 1961, the pre-EU period and the union affiliated the capitals of the EWG countries. The current name was adopted in 1993 (https:// berlin...,31.05.2018). Different still, because of its specific geographic location, is the Baltic Metropoles Network (BaltMet) which affiliates cities of nations of the Baltic basin. It was established in 2002 as the agreement of the capital of the Baltic states (Faliński, 2015).Prior 
to BaltMet, established in 1991 within the same sub-region, was the Union of the Baltic Cities that associated approximately 100 cities (http://www.ubc...,31.05.2018). Similar reginal and sub regional cooperation agreements are functioning in various parts of Europe.

The plurality and the level of activity of the international associations of the local selfgovernances demonstrate that territorially bound communities, both of a local and regional type, can join forces on the international arena. It provides them with a better forum and a platform than an individual pursuit for presentation of their common interests and for using the membership and collaboration as tools for decentralization and democratization of governance within their communities and territories. It also strengthens the standing of the cities as the natural conduit of international cooperation and exchange of ideas, knowledge and best practices (Barber, 2014).

Aside from the common to all local self-governments, there are also particular interests and needs that are specific to individual groups therefore there is an array of international organizations representing several types of local self-governance entities. All these organizations are however, intertwined and interconnected and as combined network are becoming a noticeable and influential player at the international arena. Two of the most important organizations in Europe that support the cooperation of and by the local self-governances through its specialized institutions are the European Union and the Council of Europe, and the Congress of the Council of Europe (http://www.zamp.pl...,05.06.2018).

\section{The International Cooperation of the Polish Local Self-Governances}

Neither Poland nor any of the other states of the so called "people's democracy" had been afforded the opportunity to associate and partake in the process of entering the international politics by the local self-governances prior to the last decade of the $20^{\text {th }}$ century. Primarily because none of these countries were democracies and did not have true local self-governance bodies. Although there were bodies of local governance, these were, however a part of the general centralized governing structure of the regimes. So, these were local branches of the centralized structure of the national government. The appointed rather than elected representatives of these bodies, within their limited and centrally controlled powers, cooperated and even ratified agreement with their counterparts in other countries of "people's democracy" bloc and in a limited scope even with the local self-governances from the Western Europe. On a small and limited scale Poland participated also in the "sister cities" movement. The oldest "sister city" agreement was entered by the Polish city of Rybnik (Silesia) and the French city of St. Vallier in 1961. Nine year later a cooperation agreement was signed between the Polish city of Zielona Góra and the Eastern Germany city of Cottbus (Brzozowska, 1998). In this case it was a cooperation of two cities from beyond the "Iron curtain" while the cooperation between Rybnik and St. Vallier had "lifted the curtain a bit". Both cooperation agreements were building bridges between the local communities and civil societies despite the communist hegemony within the region. These agreements are 
still in force and operating within the new democratic setting of the EU. It is important, however, to understand that the trend and the abundance of the "sister city" agreements came to Poland after 1989 following the liberation of Poland from under the Soviet imposed regime, and Poland's return to the family of democracies and law respecting countries. Today, Polish local self-governances are party to more than 4500 "sister city" agreements of which approximately 4000 are entered with European counterparts. Such proportions are obvious and understandable considering the geopolitical situation of Poland. With the changes that occurred within other countries of the former Soviet bloc, other nations of the bloc were able to join the movement as well.

Poland entering the EU in 2004 dynamized the international activity of the Polish local self-governances (Marszałek-Kawa, Lutrzykowski, 2008). Directly prior to the accession, in 2003 , there were 2131 cooperation agreements signed by the Polish local self-governances with international counterparts. In 2009 there were 4004. The greatest growth in the number of agreements being signed during the discussed period occurred among the self-governances at the County level. At the onset there were 147 agreements and by the end of the analyzed period it almost doubled going up to 438. In absolute numbers, the greatest growth occurred among the Polish communes and cities it rose from 1728 up to 3346 . The lowest growth, both as percentile and absolute numbers, occurred at the voivodship level it changed in plus from 167 up to 220 . Although the lowest, this was also an important change.

The geographical structure of the international contacts of the Polish local self-governances is also quite interesting. Dominating within the Polish cooperation, similarly to Europe in general, were the contacts with the country neighbors even with the historic enemies. Cooperation agreements with their German counterparts were at the top of the list in 2003 with the number of 644. Six years later the number was 1021 and consequently topped the list. However, changes as to the place on the list occurred regarding other countries, as presented in table 1.

Table 1. Changes in numbers and ranking of contacts between 2003 and 2019

\begin{tabular}{lcclcccl}
\hline Rank & year & Number & Country & Rank & Year & Number & Country \\
\hline $\mathbf{1}$ & 2003 & 644 & Germany & $\mathbf{1}$ & 2009 & 1021 & Germany \\
\hline 2 & 2003 & 207 & France & 2 & 2009 & 446 & Ukraine \\
\hline 3 & 2003 & 136 & Czech Republic & 3 & 2009 & 331 & Czech Republic \\
\hline 4 & 2003 & 118 & Holland & 4 & 2009 & 278 & France \\
\hline 5 & 2003 & 106 & Ukraine & 5 & 2009 & 258 & Slovakia \\
\hline 6 & 2003 & 105 & Slovakia & 6 & 2009 & 191 & Hungary \\
\hline 7 & 2003 & 97 & Denmark & 7 & 2009 & 174 & Lithuania \\
\hline 8 & 2003 & 87 & Sweden & 8 & 2009 & 173 & Italy \\
\hline 9 & 2003 & 81 & Italy & 9 & 2009 & 107 & Russia \\
\hline 10 & 2003 & 74 & Lithuania & 10 & 2009 & 86 & Holland \\
\hline 11 & 2003 & 65 & Hungary & 11 & 2009 & 84 & Sweden \\
\hline
\end{tabular}




\begin{tabular}{lcclcccl}
\hline Rank & year & Number & Country & Rank & Year & Number & Country \\
\hline 12 & 2003 & 64 & Russia & 12 & 2009 & 61 & Great Britain \\
\hline 13 & 2003 & 63 & Great Britain & 13 & 2009 & 43 & Denmark \\
\hline Total & 2003 & 1847 & & Total & 2009 & 3253 & $76 \%$ growth \\
\hline
\end{tabular}

Source: Author's own work

As presented in the table there was $76 \%$ growth in the overall number of contacts. As to the ranking, other than Germany who retained the leading position with almost $60 \%$ increase, the major change occurred respectively in contacts with Ukraine a fourfold growth moving from the $5^{\text {th }}$ to the $2^{\text {nd }}$ position in the ranking and the Czech Republic a twofold growth with the Czech Republic retaining its $3^{\text {rd }}$. France dropped down from the $2^{\text {nd }}$ to the $4^{\text {th }}$; Slovakia moved up from $6^{\text {th }}$ to $5^{\text {th }}$; Hungary went up from $11^{\text {th }}$ to $6^{\text {th }}$; Lithuania claimed up from $10^{\text {th }}$ to $7^{\text {th }}$; Italy up by 1 from $9^{\text {th }}$ to $8^{\text {th }}$; Russia up from $12^{\text {th }}$ to $9^{\text {th }}$; Holland down from $4^{\text {th }}$ to $10^{\text {th }}$; Sweden down from from $8^{\text {th }}$ to $11^{\text {th }}$; Great Britain up by 1 from 13 to $12^{\text {th }}$ and Denmark down from 7 to $13^{\text {th }}$.

Based on the presented data, regarding the thirteen territorial self-governments with which their Polish counterparts remained in contact, several important conclusions can be drown. First - Germany was at the lead in 2003 and has retained the lead position in 2009; second - Ukraine, our direct neighbor, who is not a member of the EU has claimed to the second position in the ranking; third - our historical ally and by many considered a friend is no longer among the leaders within the framework of the cooperation at the level of local self-governance; fourth - a significant growth occurred in regard to cooperation with our Southern neighbors the Czech Republic and Slovakia and other countries of the region, particularly Hungary, Lithuania and even, although on a smaller scale, with Russia; fifth - a certain stagnation or in some cases regress (Denmark) has been experienced in regard to the contacts at the self-governance level between Poland and some countries of Western Europe and Scandinavia (Great Britain, Holland, Sweden). Italy, with the contacts still growing, is the exception to this situation. In general, it can be concluded that Poland is not breaking out of the general European trend that the most intense international cooperation and contacts at the level of local self-governance occurs among the closest and the nearby neighbors.

To present the whole picture it seems necessary to briefly discuss the data regarding the international cooperation and contacts by the Polish self-governance bodies with their counterparts from outside the EU. These are relatively low in numbers and intensity. Measured as percentile, the strongest growth occurred in relation to cooperation w Turkey, which may be related to the Turkish aspiration for EU membership. In 2003 there was only one pair of sister cities. In 2009 there were 22 of such twin-cities, which constitutes an increase by $2200 \%$. In the same period the growth with Serbia was at $1100 \%$ - a half of the growth with Turkey. The third country within this group is Norway. In 2003, there were only two 
sets of twin cities established by Polish and Norwegian local-self-governance bodies. In 2009 there were 12 (600\% growth).

Moreover, during the discussed period of six years the Polish local self-governances not only continued to expand relationships by entering into new contracts within the countries in which territories partnerships were already in place but proceeded to enter into cooperation contracts within countries where there no previous contracts or contacts with local self-governances. The process was still low key in terms of intensity yet still important from the perspective of the future potential. There were 3 agreements executed with Georgia, 2 with each of the following Armenia, Mongolia, Taiwan, Chechnya, and singular agreements were executed within the following countries: India; Ecuador; Kyrgyzstan; Macedonia; and Lebanon (Faliński, 2011).

\section{Conclusions}

The presented below research material provides the basis for the positive verification of the hypothesis presented at the onset of this discourse. The conclusions presented below are the final result of the research process discussed herein. These conclusions pertain to the cooperation between the local self-governments themselves as well as to the international environment in which the cooperation is carried out. The conclusions are presented in two distinct groups. Presented first are the conclusions regarding the immediate sphere of the internationally cooperating local self-governments and the territorially defined communes which they represent. Following are conclusions regarding the international setting in which the cooperation is carried out.

I. The international cooperation by the local self-governments impacts the local communities and their self-governing bodies in the following ways:

- Constitutes a subsequent activity being undertaken by a commune because of which the internal ties and the feeling of shared goals, belonging and commitment deepens and further develops;

- Provides a point of reference for evoking and developing a local and regional identity that is distinct and separate from others;

- Constitutes an information venue through which friendly and open to cooperation local communities and their self-governances deliver information about themselves;

- Provides opportunities for self-assessment and comparison of one's own local community with others;

- Teaches how to respect and appreciate other cultures;

- Instils tolerance among the members of the local communities toward other, different local communities with different civilization and cultural backgrounds;

- Awakes an interest among the members of a local community toward the surrounding world; 
- Constitutes a source of knowledge and experiences regarding the surrounding world;

- Is conducive to building the notion that pluralism and differences constitute are rather enriching stimuli;

- Helps to break down and forego negative cultural and civilization barriers and stereotypes;

- Enhances and supports economic development through establishing economic cooperation at a local level;

- Brings about possibilities to seek and apply for the structural assistance funding from the EU;

- Promotes and helps the members of the local community to understand and embrace the universal values that are common to all culturally diverse communities and persons

II. The international cooperation by local self-governments and their territorially defined communities impacts the international environment in the following ways:

- It exceedingly more powerful and efficient in establishing ties and building effective local partnership than cooperation by state governments at the national level;

- It is conducive to developing authentic and relatively permanent agreements and open, friendly, effective and lasting work relationships between the citizenry of local communities and their self-governance bodies as oppose to relationships between institutions as it is the case with national governments;

- It builds positive relations among the members of the working together local communities;

- It promotes cultural diversity and serves as conduit for the transfer of knowledge regarding distinct cultures and values;

- It evokes openness, tolerance and appreciation of different culture and civilizations;

- It helps to break down barriers and negative stereotypes by promoting knowledge;

- Significantly contributes to the improvement of international cooperation at all levels among different democratic nations, local communities, organizations and individuals;

- Helps to build positively charged networks and build lasting societal relationship and ties that are rooted not in the formal contacts carried out by public administrations but based on direct interactions of people from local communities and their local self-governance bodies.

- Aids in building international order and peace that is deeply rooted first on the cooperation at a local level with hands-on experience and deep understanding 
of local problems a sizable portion of which is caused by or rooted in analogous situation;

- Thanks to its decentralized form and an approach to governance promotes civic mindset and democratic governance respectful of and upholding the law;

- By strengthening the local self-governances and their international cooperation strengthens the role of the local self-governance bodies within their respective countries.

\section{Bibliography}

Barber, B. R. (2014). Gdyby burmistrzowie rzadzili światem. Dysfunkcyjne kraje, rozkwitające miasta. Warsaw: MUZA.

Bielecka, M. (2006). Komitet Regionów Unii Europejskiej a integracja europejska, Warsaw: CeDeWu.

Brzozowska, A. (1998). Partnerstwo ponad podziałami. In Brzozowska, A. (ed.), Zwiazki bliźniacze. Wspótpraca międzynarodowa samorządów lokalnych. Poznań: Związek Miast Polskich.

Faliński, S. (2015). Aktywność międzynarodowa Warszawy. Kwartalnik Naukowy Uczelni Vistula, No. 3/45.

Faliński, S. (2011). Wspótpraca międzynarodowa samorządów terytorialnych. Studia i analizy dyplomacji kulturalnej i publicznej, No. 2.

Honka, N. (2002). Wspótpraca samorzadu terytorialnego województwa opolskiego z partnerami zagranicznymi wobec integracji europejskiej. Stan obecny. Szanse i zagrożenia. In B. Nitschke (ed.), Europa regionów. Tradycje i perspektywy. Zielona Góra: Regionalne Centrum Animacji Kulturalnej.

http://www.ccre.org/

http://www.eurocities.eneurocities/about_us

http://www.zmp.poznan.pl/strony/kong...okalnych-i-regionalnych-europy-clrae

http://www.ubc.net/cities

https://www.aer.en/aer-largest-independent-network-regions-wider-europe/

https://www.berlin.de/rbmskzl/en/international-relations/city-networks/ucue/arttikel.23474.en.php

https://www.ludwigsburg.de/Lde/start/stadt_buerger/Internationales.html

https://www.uclg.org/

Jaczynowska, M., Mączakowa, A., Tyloch, W. (1974). Historia starożytna. Warsaw: Wydawnictwa Szkolne i Pedagogiczne.

Jóśkowiak, K. (2002). Wspótpraca transgraniczna i międzyregionalna Polski u progu członkostwa w Unii Europejskiej. Samorząd terytorialny, No. 5.

Kaczmarek, T. (2005), Struktury terytorialno-administracyjne i ich reformy w krajach europejskich, Poznań: Wydawnictwo Naukowe UAM.

Marszałek-Kawa J., Lutrzykowski A. (eds.), (2008). Samorzad terytorialny w Polsce i w Europie (doświadczenia i nowe wyzwania). Toruń: Wydawnictwo Adam Marszałek.

Modzelewski, W. T., Żukowski, A. (2007). Polski samorzad w stosunkach międzynarodowych. Zarys problematyki. In Marszałek-Kawa, J. (ed.), Samorzad terytorialny. Studium politologiczne. Toruń: Wydawnictwo Duet.

Piasecki, A. K. (2002). Polityka zagraniczna jednostek polskiego samorzadu terytorialnego. In B. Nitschke (ed.), Europa regionów. Tradycje i perspektywy. Zielona Góra: Regionalne Centrum Animacji Kulturalnej. 
Paczyńska, K., Stachowiak A., Porawski A., Leki H. (eds.) (2009). Współpraca partnerska samorządów. Praktyczny przewodnik, Poznań: Związek Miast Polskich.

Ruszkowski, J. (2003). Pomorze Zachodnie w północnym wymiarze Unii Europejskiej. In Wojtaszak, A. (ed.) Pomorze Zachodnie wobec Unii Europejskiej. Szczecin: Wydawnictwo Naukowe Uniwersytetu Szczecińskiego.

Swianiewicz, P. (2005). Kontakty międzynarodowe samorząów. Samorząd terytorialny, No. 10.

\section{Author}

\section{Assoc. Prof. Stanisław Faliński}

Siedlce University of Science and Humanities, Faculty of Economic and Legal Sciences. Contact details: sfalinski@onet.pl 